\title{
Initial dynamic system design for optimization of gravity irrigation water management (open gravitation irrigation)
}

\author{
Asep Kurnia Hidayat ${ }^{1}$, R. Reza El Akbar ${ }^{2}$, Ai Sri Kosnayani ${ }^{3}$ \\ ${ }^{1}$ Department of Civil Engineering, Universitas Siliwangi, Indonesia \\ ${ }^{2}$ Department of Informatics Engineering, Universitas Siliwangi, Indonesia \\ ${ }^{3}$ Departement of Nutrition, Universitas Siliwangi, Indonesia \\ Jl. Siliwangi No. 24 Tasikmalaya 46115, Indonesia, Telepon (0265) 330634 Faksimil (0265) 325812 \\ *Corresponding author, e-mail: asepkurnia@unsil.ac.id
}

\begin{abstract}
The condition of available water is smaller than the need for irrigation water for agricultural land that is needed is an expression of conflict in the field. To overcome this problem is a regulation of several parameters, including regulation of planting schedules and reduction of land area. The model of the irrigation water management system used is based on the risk of land failure and the optimum area of land that can be planted. The parameters used to overcome this problem are planting schedules, risk of land failure and factor $k$. The $k$ factor is the ratio of water availability to water needs. The output of this system is optimal net benefit based on the optimal alternative irrigated land area. The results of the formula will show the optimal amount of land area that produces optimal net benefits based on certain planting schedules and certain effective rainfall. This system will also show that optimization will be achieved if there is a water balance between the availability and needs of irrigation water. The system referred to in this study is a dynamic system. The purpose of this study is to make a preliminary design of a dynamic system to optimize the irrigation system of agricultural land. The results obtained in this study were in the form of feedback loops and interactions between loops with each other in agricultural irrigation systems.
\end{abstract}

Keywords: dynamic systems, irrigation, optimization of water needs

Copyright $(9) 2019$ APTIKOM - All rights reserved.

\section{Introduction}

Irrigation is the use of water on the ground for the purposes of providing the liquid needed for the growth of plants. The water is obtained from five sources, namely (1) precipitation, (2) atmospheric water other than precipitation, (3) flood water, (4) ground water, (5) irrigation [1]. Availability of water is the main problem considered in determining cropping patterns in irrigation areas. Considering the importance of irrigation activities, it is necessary to do optimal water utilization planning so that the maximum profit from the available water supply is in accordance with its functions [2].

Equilibrium conditions in irrigated land are the availability of irrigation water and irrigation water needs. Water availability in irrigated land is effective rain whereas irrigation water needs are water needs to replace water loss due to land management, evapotranspiration, percolation and inundation of irrigation land. Water balance, which is the ratio between water demand and water available, is considered to exceed the critical point or is considered to be in danger of getting a water deficit if it reaches above $75 \%$ [3].

Actually, there are two conditions of water equilibrium that occur in irrigation water conditions, namely equilibrium when processing land and conditions during planting. The condition of water balance at the time of planting is the condition of the availability of water greater or equal to the water requirements for water treatment, commonly called the IR (Irrigation Requirement), while the condition of water balance at the time of planting is a condition of availability greater or equal to the need for water to replace water which is lost as long as the plant is planted until harvest, which is usually called NFR (Net Field Requirement). The volume equilibrium model has become the basis for most planning and evaluation procedures in the field and has been proven by field and laboratory data [4].

The condition of not occurring equilibrium, namely the condition of water availability smaller than irrigation water needs is an expression of conflict in the field that requires management that is not simple. In the distribution of water emphasizes justice in obtaining water. Therefore, a technical system was used tek-tek system by considering the proximity of the irrigated rice fields and selecting systems when the water 
that was not entirely flowed into the rice fields. [5] It was further stated that optimization will be achieved if there is a water balance between water availability and irrigation water needs. [6]

Research on irrigation management has been carried out using a technical approach, among others: (1) research on irrigation water needs with observations in the field of evapotranspiration, percolation, evacuation, water discharge, physical properties of the soil. (2) research in the laboratory in the form of soil testing to determine soil texture and permeability coefficient by comparing the results in the laboratory and observing inflow outflow, percolation, evaporation and transpiration in rice fields. (3) research on water requirements on critical land through a bamboo channel system to determine the physical condition and texture of the soil in water absorption. (4) the provision of a system of giving irrigation water to isolated land to determine the system of providing irrigation water in the dry season by doing minimal giving and plant growth with a system of evaporation from dew, and it turns out that from several studies it is still not optimal in finding appropriate irrigation management [7].

Water allocation is a concern in developing countries where water resources are limited and demand is greater with more parties [8]. Surface irrigation is an irrigation system that taps water directly in the river through weir buildings or through free intake buildings, then irrigation water is channeled gravitationally through channels to agricultural land [9].

Optimization of water use for irrigated land can be said as irrigation efficiency, it is also one of the energy savings. Efficiency of water use and efficiency of energy use are the two main focuses of the latest innovations in smart irrigation and SMS grid. The problem of distribution of irrigation water usually occurs in the irrigation area farthest from the intake water. [10]. Other experts argue that lack of irrigation water is a challenge that often occurs in the furthest canals (Canal Tail-end / CT) [11]. Optimization of irrigation water is a very important component in irrigation water management. [6]. Furthermore, it is said that optimization will be achieved if there is a water balance between water availability and irrigation water needs. Louks suggests that simulation techniques are an effective method for evaluating water use allocation targets and are relatively simple than others [12]. Furthermore, Carr and Underhill suggested that simulation is an aid in planning water resources development, especially in the matter of optimization of irrigation systems [12].

Dynamic system is a method used to describe, model, and simulate a dynamic system (time constantly changing). In a dynamic system are taught how to think in a system. It means that in solving a problem, it is not seen in one point only, but it is seen by all of its effects on all related to the problem. System dynamics is an approach to understanding complex system behavior over time. It deals with internal feedback and time delays that affect the behavior of the entire system [13].

The problem of risk of land failure due to water equilibrium that occurs in existing irrigation areas, namely irrigation areas after the structure or irrigation area that is operating which due to many factors in the field, will certainly experience many changes in its operations so that it is no longer compatible with conditions at the time of planning, not yet much researched. Risk can be defined as the chance of an adverse event, which is caused by the uncertainty of what will be faced. [14] This study offers a mathematical formula for optimization of risk-based irrigation-based irrigation water management systems, formulas in this system are expected to predict the extensive risk of land failure from existing irrigation areas, extensive optimism that can be irrigated and door operations from the take-up gate (intake) at the location of the weir and several building doors for. This system can be applied to irrigation areas with limited water availability or where water availability is smaller than irrigation area water requirements. The regulation is based on fixed parameters and the parameters change. Parameters needed are cropping patterns, types of rice varieties, planting schedules, effective rainfall, water availability at the door and irrigated area.

Based on the description of the background above, this study is very important because around $77 \%$ of districts and cities are predicted to have 1-8 months of water deficit in a year, even in 2025 , it is estimated that districts and cities have a water deficit of up to $78.4 \%$ with deficits ranging from $1-12$ months or a year-long deficit. [15]. InaRisk data from the National Disaster Management Agency (BNPB), the risk of drought in Indonesia reaches 11.77 million hectares each year and afflicts 28 provinces so there is a risk of greater crop failure [16]. FAO data, Indonesia only uses $3 \%$ of the total actual renewable water resources (Total actual renewable water resources / TARWR) where the highest percentage is $91 \%$ for the use of the agricultural sector [17].

\section{Research Methods}

The method in this study refers to the stages in the dynamic system, but for this initial design only three main stages of the dynamic system are carried out, namely the identification of problems, determining 
the dominant factors for the problem, tracking the feedback loop and the interaction between loops and others.

\subsection{Stages of problem identification}

At this stage identification of problems that arise from existing irrigation systems is carried out, and at this stage conclusions are identified to identify existing problems. The process of identifying this problem is carried out after going through an initial observation study in the field regarding problems that often arise and arise in the optimization of irrigation.

\subsection{Dominant factors}

At this stage, the dominant factors for the system will be determined. These factors are generated from the results of observations, literature studies and brainstorming. The dominant factor raised by one of them is based on previous research stating that optimization will be achieved if there is a water balance between water availability and irrigation water needs [6].

\subsection{Feedback loop and interaction between loops}

At this stage the process flow diagram is determined which shows the interaction between the dominant factors and influences on the system to be built. At this stage a process flow diagram appears along with feedback and interaction between loops.

\section{Results and Analysis}

\subsection{Identify research problems}

Based on the background related to these problems, the conditions that are always changing in the irrigation area during planning and post-structure, so that the evaluation of irrigation water evaluation and planning (IWEP) is needed, so the identification of the problem is formulated as follows:

a. Determining the planting schedule needs to be done with consideration to obtaining optimum land area and inimizing the risk of failure of irrigated area,

b. The operation of the sluice gate needs to be considered especially in the building of the intake door (intake), building door for 1 , and building doors for those that are reviewed in order to minimize the risk of land failure,

c. Parameters that affect the extent of land failure, for example, planting schedules, available water discharge, irrigation water requirements for the risk of land failure, need to be taken into account.

d. The model of the relationship between the planting schedule, available water discharge, and irrigation water requirements against the risk of land failure. Built as an initial stage in the creation of a dynamic system.

\subsection{Forming factors of the early model}

- The availability of water resources calculated in this study is water resources in the form of a definitive debit (measurement results). Definitive discharge in the form of daily debit $\left(\mathrm{m}^{3} / \mathrm{sec}\right)$ at the intake. Available water discharge or inflow at the intake is used $80 \%$ mainstay water discharge is fulfilled [18].

- Irrigation water requirements in land (KAIL or NFR) for plants have $\mathrm{mm} /$ day units which are converted into L / sec / ha units [19]. KAIL is formulated as follows:

$$
K A I_{L}=E t c+P+W L R-H E\left(\frac{m m}{h a r i}\right)
$$

thus, the unit irrigation water discharge:

$$
Q A I_{P}=(E t c+P+W L R-H E) \cdot A\left(\frac{L}{\operatorname{detik}}\right)
$$

while the irrigation water discharge taken is a function of $Q A I_{p}$, losses and efficiency

$$
Q A I_{p t}=\mathrm{f}^{*}\left(Q A I_{P}, \text { Losses dan Efisiensi }\right)
$$

Water requirements for plants or consumptive use (Etc) are interpreted as evapotranspiration of reference plants, by including the factor coefficient of plants, so that [19]:

APTIKOM J. CSIT Vol. 4, No. 2, 2019: $74-80$ 
with,

$$
\text { Etc }=k c . E t o\left(\frac{m m}{\text { hari }}\right)
$$

Eto $=$ reference plant evapotranspiration $(\mathrm{mm} /$ day $)$

$\mathrm{Kc}=$ plant coefficient

Water requirements for land preparation (IR) generally determine the maximum need for irrigation water. To calculate water requirements during land preparation, the method developed by van de Goor and Zijlstra (1968) was used. The method is based on a constant water rate in L / sec during the land preparation period and produces the following equation [19]:

with,

$$
I R=M\left(\frac{e^{k}}{e^{k}-1}\right)(m m / d a y
$$

$\mathrm{IR}=$ irrigation water needs at paddy level ( $\mathrm{mm} /$ day)

$\mathrm{M}=$ water needs to replace / compensate for water losses due to evaporation and percolation in saturated fields (mm / day)

$\mathrm{M}=\mathrm{Eo}+\mathrm{P} \mathrm{Eo}=1,1$ Eto

$\mathrm{P}=$ percolation $(\mathrm{mm} /$ day $)$

$\mathrm{k}=\mathrm{MT} / \mathrm{S}$

$\mathrm{T}=$ land preparation period (days)

$\mathrm{S}=$ water requirement for saturation $(\mathrm{mm})$ plus $50 \mathrm{~mm}$ water layer

$\mathrm{e}=$ napier number

The percolation and seepage rate is very dependent on the properties of the soil. In heavy clay soils with good processing characteristics, the percolation rate can reach 1-3 mm / day. On lighter soils the percolation rate can be higher. To determine the percolation rate, groundwater level must also be taken into account. Seepage occurs due to seepage of water through the rice field embankment. In this study percolation and seepage were assumed to be $2 \mathrm{~mm} /$ day [20].

Water Layer Replacement (WLR) is carried out twice, $50 \mathrm{~mm}$ each for a month or $3.3 \mathrm{~mm} /$ day for half a month, this replacement is carried out two months after transplantation or removal of seedlings. In this $\mathrm{su}=$ tudi water replacement is done twice or two months each $50 \mathrm{~mm} /$ month or $1.7 \mathrm{~mm} /$ day [20].

Effective Rainfall according to Irrigation Standards and Criteria [19], for rice irrigation effective monthly rainfall is taken $70 \%$ of the minimum monthly rainfall with a 5 -year return period, or $\mathrm{H} 80 \%$.

wiith,

$$
H E=0,7 \times\left(\frac{1}{15}\right) H_{80 \%}
$$

$\mathrm{HE}=$ effective rainfall $(\mathrm{mm} /$ day)

$\mathrm{H} 80 \%=$ middle monthly rainfall $80 \%$ dry $(\mathrm{H} 80 \%)$

Daily debits analyzed to fifteen daily average debits are then calculated to be a mainstay discharge of 80\% fifteen daily (Q80\%). Mainstay discharge of 80\% fifteen daily (Q80\%) is determined by Weibul's equation [17], namely:

with,

$$
P\left(X \geq X_{m}\right)=\frac{m}{n+1}
$$

$\mathrm{P} \quad=$ probability of plan $(\%)$,

$\mathrm{X}=$ andom variable,

$\mathrm{X} \_\mathrm{m}=$ probability distribution related to rank $\mathrm{m}$,

$\mathrm{m}=$ ranking position

$\mathrm{n}=$ number of years 
The purpose of this research is to maximize the profits of agricultural products from irrigation areas which can be compiled from the following equation:

with,

$$
\operatorname{Max}=\Sigma C_{i j T} X_{i j T}-R g I_{i j T}
$$

$\operatorname{RgIijT}=$ cost of risk of failure of planting land for each type of crop $\mathrm{i}$ with a planting schedule $\mathrm{j}$ in one planting season $\mathrm{T}$ (Rp.)

$\mathrm{Cij} \mathrm{T}=$ profit per hectare obtained from each type of crop $\mathrm{i}$ with a planting schedule $\mathrm{j}$ in one planting season T (Rp. / Ha)

$\mathrm{XijT}=$ decision variable (optimal area of each type of crop i with a planting schedule $\mathrm{j}$ in one planting season $\mathrm{T}(\mathrm{ha})$

Benefit is the result of multiplying profits / ha for each type of plant with the planting area in one year of the planting season (the production price is considered constant for each planting schedule). So that benefits are calculated by the following formula:

with,

$$
B_{i T}=C_{i T} X_{i T}
$$

$\mathrm{BiT}=$ crop benefits $\mathrm{i}$ in the $\mathrm{T}$ planting season $(\mathrm{Rp}$.

$\mathrm{CiT}=$ profit of crop i per hectare in the planting season $\mathrm{T}(\mathrm{Rp} . / \mathrm{Ha})$

$\mathrm{XiT}=$ plant area $\mathrm{i}$ in the planting season $\mathrm{T}(\mathrm{ha})$

The equation approach for the cost of risk of failure of planting land for each planting schedule $\mathrm{j}$ in the year effective $\mathrm{h} \%$ and planting area $\mathrm{X}$ is as follows

$$
R g I_{j h x}=I n \cdot R g a \cdot\left(1-(R e)^{\frac{Q A I-p t}{Q \text { andalan }}}\right) \cdot X C \text { Rupiah }
$$

with,

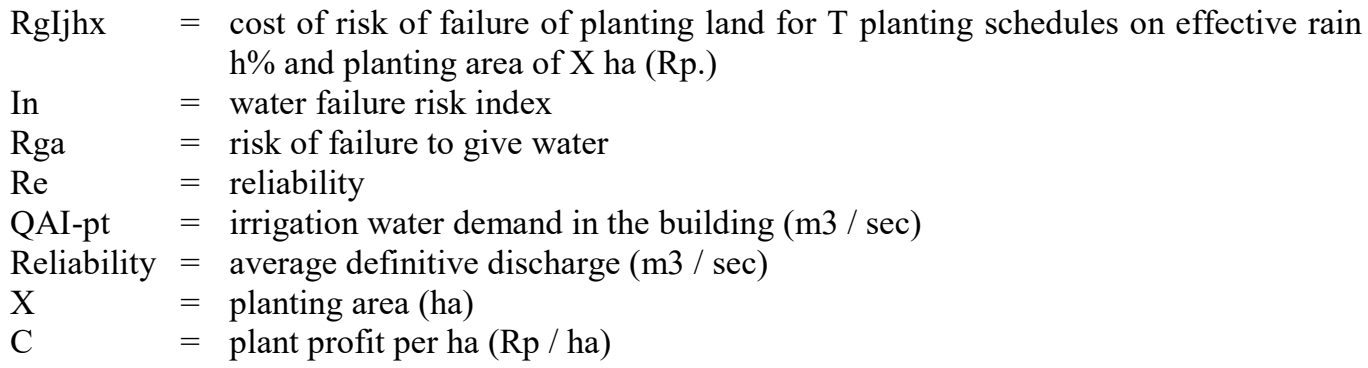

\subsection{Model and interaction between factors}

Irrigation is the most important infrastructure of agriculture. Accurate irrigation planning must be accompanied by post-structure irrigation management. In irrigation areas, the problem of distribution of irrigation water often occurs if the amount of available discharge is smaller than the water requirements in the field (especially during the dry season). So that efficient use of irrigation water is needed. The results of irrigation production (harvest) are influenced not only by the many levels of fulfillment of water needs, but also by the way of giving water [21-23] Data in irrigation planning are mostly dynamic and empirical data so that there is no possibility of distortion with real data. The failure of the land in question is the failure of an irrigation system that is unable to irrigate the available irrigation area. Planned irrigation areas cannot always be completely irrigated by the system, irrigation areas that cannot be irrigated will cause crop failure, so that land failure can be identified with crop failure. The causes of land failure or crop failure can be varied, among others, (1) water availability is smaller than irrigation water needs, (2) the availability of extreme irrigation water is greater than irrigation water needs so it becomes uncontrolled in a relatively long time and causes plants die because their roots rot submerged (3) the lack of discipline of users of irrigation water so that water regulation becomes chaotic. In this study, we will discuss the first cause, namely a condition where water availability is smaller than irrigation water needs. Conditions where the availability of water is smaller than irrigation water needs has a wider impact, besides the impact of land failure or crop failure can also cause social impacts, namely friction occurs at the level of users of irrigation water because of fighting over water.

APTIKOM J. CSIT Vol. 4, No. 2, 2019: $74-80$ 
Land failure or crop failure almost occurs every planting season, especially in the dry season. Some studies for land failure or crop failure have been carried out, but no research has regulated how irrigated areas should be planted so that land failures or crop failures do not occur.

This study offers an evaluation model and solution to irrigation areas post structure so that there is an optimization of the use of water so that the maximum yield of agricultural production can be obtained by reducing irrigation areas. The output to be obtained is the optimal area of land that may be planted, the risk of the area of land that cannot be planted and the operation of sluice gates in buildings for tertiary plot supply or tertiary plot sets. The optimum condition is achieved when there is an equilibrium between the availability of water and the needs of irrigation water.

Based on the results of a search of the dominant factors that influence the optimization of the irrigation system of agricultural land, the initial model for designing a dynamic system is obtained, as can be seen in Figure 1 below:

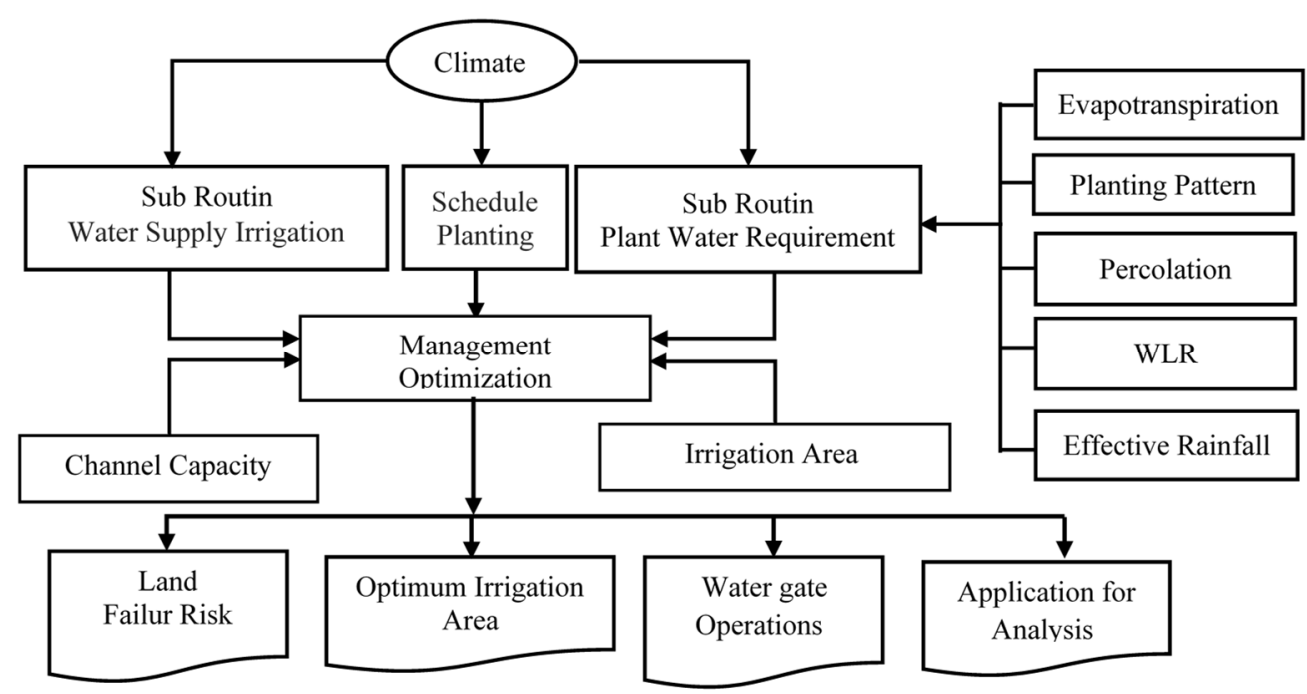

Figure 1. Initial model of dynamic system optimization of gravity irrigation systems

\section{Conclusion}

Based on the results of the research steps, the initial model of the dynamic system will be obtained. The model shows the dominant factors that influence the optimization of irrigated agricultural land systems. Further research needs to be done to present and perform simulation calculations and determine the validity of the models made.

\section{References}

[1] Hansen, V.E., Israelsen, O.W. Stringham, G.E., Tachyan, E.P., Soetjipto, Dasar dasar dan Praktek Irigasi, Jakarta: Penerbit Erlangga. 1986

[2] Nadjamuddin, D, F., Soetopo, W., Sholichin M. Rencana Penjadwalan Pembagian Air Irigasi Daerah Irigasi Paguyaman Kanan Kabupaten Boalemo Provinsi Gorontalo, Jurnal Teknik Pengairan. 2014; 5(2):158-165

[3] Kusumosanyoto, S. Pembangunan sumberdaya air dalam dimensi hamemayu hayuning bawono. Hasta Cipta Mandiri. Yogyakarta. 2009.

[4] Wynn R. Walker. Gaylord V. Skogerboe. Surface Irrigation Theory and Practice, PRENTICE-HALL, INC., Englewood Cliffs, New Jersey 07, 1987.

[5] Aryawan, I.P.S., Windia Wayan., Wijayanti.P. U. Peranan Subak dalam Aktivitas Pertanian Padi Sawah (Kasus di Subak Dalem, Kecamatan Kerambitan, Kabupaten Tabanan). E-jurnal Agribisnis dan Agrowisata. ISSN: 2301-6523. 2013; 2(1):1-11.

[6] Hidayat, Asep Kurnia. Model Optimasi Pengelolaan Air Intake Lakbok Selatan Bendung Gerak Manganri. Thesis. Yogyakarta: Universitas Gadjah Mada. 2001.

[7] Supadi. Model Pengelolaan Irigasi Memperhatikan Kearifan Lokal. Desertasi. Semarang: Universitas Diponegoro, 2009.

[8] Marselina, M., Sabar, M., Salami, I.R.S., Marganingrum, D., Model Prakiraan Debit Air dalam Rangka Optimalisasi Pengelolaan Waduk Saguling - Kaskade Citarum, Jurnal Teknik Sipil. 2017;24(1): 99-107. 
[9] Wiryawan, A.G.P., Norken, I.N., Purbawijaya, I.B.N., Efektifitas pengelolaan irigasi dengan sumur pompa guna meningkatkan pola tanam di Kecamatan Negara Kabupaten Jembrana, Jurnal Spektran. 2016; 4(1): 88-96.

[10] Nisiakou, A, Vavalis, M, Zimeris, D, Smart energy for smart irrigation, Computer and Electronics in Agriculture. 2016; 129: 74-83

[11] El-Nashar, W.Y., Elyamany, A.H., 2017, Value Engineering for Canal Tail Irrigation Water Problem, Ain Sham Engineering Journal. 2017; 1-9.

[12] Syafrial, Optimasi Pemanfaatan air tersedia untuk irigasi dengan metode simulasi, UGM, Yogyakarta. 1994

[13] Forrester, J.W. Some Basic Concepts in System Dynamics. Sloan School of Management Massachusetts Institute of Technology. 2009

[14] Norken, I.N., Purbawijaya, I.G.N., Oka Saputra, I.G.N, Pengantar Analisis Dan Manajemen Risiko Pada Proyek Konstruksi, Udayana University Press. 2015.

[15] Arumingtyas, Lusia., Apriando, Tommy, Krisis Air Berlanjut, Belasan Ribu Hektar Lahan Pertanian Gagal Panen. 2017. http://www.mongabay.co.id/2017/09/15/krisis-air-berlanjut-belasan-ribu-hektar-lahan-pertaniangagal-panen/15 Sep 2017.

[16] Syarif, Mohar, Peneliti: Kemarau Panjang Penyebab Risiko Gagal Panen. 2018. http://www.neraca.co.id/article/107585/peneliti-kemarau-panjang-penyebab-risiko-gagal-panen12 Okt 2018

[17] Yekti, M.I., Schultz, E., Norken, I.N., Hayde, Laszlo, Role of Reservoir Operation in Sustainable Water Supply to Subak iirigation Schemes in Yeh Ho River Basin, CRC Press/Balkema, Netherlands. 2017.

[18] Rudy, Lisa Jo, Solve 80\% of Your Problems with Pareto Analysis. 2014. https://business.tutsplus.com/articles/solve-80-of-your-problems-with-pareto-analysis--cms-21289.

[19] Direktorat Jenderal Pengairan, Departemen Pekerjaan Umum, Buku Petunjuk Perencanaan Irigasi, C.V. GALANG PERSADA, Bandung. 1986.

[20] Direktur Perguruan Tinggi Swasta, Irigasi Dan Bangunan Air, Jakarta, Penerbit Gunadarma. 1997.

[21] Ahmad, M.D., Masih, I., \& Turral, H., Diagnostic Analysis of Spatial and Temporal Variations in Crop Water Productivity, Journal of Applied Irrigation Science. 2004; 39(1): 43-63.

[22] Erdem, T., Erdem, Y., Orta, H., \& Okursoy, H., Water-Yield Relationships of Potato under Different Irrigation Methods and Regimens, Journal of Science and Agriculture. 2006; 63(3): 226-231.

[23] Khan, M.H., \& Saleem, N., Influence of Different Irrigation Intervals on Growth and Yield of Bell Pepper, Research Journal of Agriculture and Biological Science. 2005; 1(2): 125-128. 